\title{
PENERAPAN PENILAIAN KINERJA PADA PEMBELAJARAN SEKOLAH DASAR
}

\author{
Risa Listyaningrum, Sri Estu Winahyu, Muchtar \\ Universitas Negeri Malang, Jalan Semarang 5 Malang 65145 \\ E-mail: risalistyaningrum19@gmail.com
}

\begin{abstract}
The purpose og this research is: (1) planning the performance assessment; (2) the implementation of performance assessment; and (3) report on the performance evaluation results of learning in the fifth class of Public Elementary School Blimbing 3 Malang (Sekolah Dasar Negeri Blimbing 3 Malang). This research used a descriptive qualitative approach in case study. The data is collected through observation, interviews, and documentation. The results showed that: (1) the preparation of integrated performance assessment plan in the course plan (RPP) in even semester consisting of Theme 5 to Theme 9 cannot be found because teachers do not prepare lesson plans; (2) the implementation of performance assessment is not done thoroughly by teachers, as they have difficulty in time management and teachers focused on a material with a performance assessment; (3) the implementation of performance assessment conducted by teachers in even semester consisting of Theme 5 to Theme 9 are not yet fully accordance with the measures of performance appraisal. This is proven by the performance assessment of the teachers which do not deliver the performance assessment rubric to students, the time management is not well-organized, and how teacher just memorize in assessing the learners, making the result less maximum; and (4) the report of performance assessment conducted by the teacher is already good, proven by how meaningful the report card reporting performance appraisal in the form of numbers, title, and description. However, teachers have a hard time in processing the outcome score of learners.
\end{abstract}

Keywords: performance assessment, instructional, 2013 curriculum

\begin{abstract}
Abstrak: Penelitian ini bertujuan untuk mendeskripsikan: (1) perencanaan penilaian kinerja; (2) penerapan penilaian kinerja; dan (3) pelaporan hasil penilaian kinerja pada pembelajaran di kelas V SDN Blimbing 3 Kota Malang. Penelitian ini menggunakan pendekatan deskriptif kualitatif studi kasus. Pengumpulan datanya melalui observasi, wawancara, dan dokumentasi. Hasil penelitian menunjukkan: (1) penyusunan perencanaan penilaian kinerja yang terintegrasi di RPP Semester Genap yang terdiri dari Tema 5 sampai Tema 9 tidak ada karena guru tidak menyusun RPP; (2) penerapan penilaian kinerja tidak terlaksana semuanya karena guru kesulitan pada waktu perlaksanaannya dan guru terfokus pada satu materi dengan satu penilaian kinerja; (3) penerapan penilaian kinerja yang dilakukan oleh guru di Semester Genap yang terdiri dari Tema 5 sampai Tema 9 belum sepenuhnya sesuai dengan langkah-langkah penilaian kinerja. Hal ini terbukti pada penilaian kinerja karena guru tidak menyampaikan rubrik penilaian kinerja pada peserta didik, waktu yang digunakan tidak teroganisir dengan baik, dan dalam menilai peserta didik guru hanya mengingat-ingat sehingga kurang maksimal dalam menilai; dan (4) pelaporan penilaian kinerja yang dilakukan oleh guru yaitu sudah baik, terbukti dari pelaporan penilaian kinerja di rapor berbentuk angka, predikat, dan deskripsi yang bermakna. Namun guru memiliki kesulitan waktu pengolahan nilai peserta didik.
\end{abstract}

Kata kunci: penilaian kinerja, pembelajaran, kurikulum 2013

Penilaian merupakan bagian integral dari pembelajaran. Penilaian tersebut dapat dilakukan meliputi berbagai aspek, yaitu aspek sikap, aspek pengetahuan, dan aspek keterampilan. Hal ini telah ditegaskan dalam Peraturan Menteri Pendidikan dan Kebudayaan Nomor 53 Tahun 2015 tentang Penilaian Hasil Belajar oleh Pendidik dan Satuan 92 
Menengah menyatakan bahwa pengumpulan data tentang perkembangan kompetensi peserta didik pada pembelajaran dilakukan pada aspek sikap, pengetahuan, dan keterampilan. Penilaian pada aspek keterampilan salah satunya dapat dilakukan melalui penilaian kinerja.

Penilaian kinerja merupakan penilaian yang dilakukan guru untuk menilai peserta didik dalam mendemontrasikan tugas tertentu setelah mereka memiliki kompetensi yang dimilikinya. Penilaian kinerja sangat dianjurkan dalam Kurikulum 2013 karena peserta didik akan diamati dan dinilai bagaimana mereka dapat bergaul, bagaimana mereka bersosialisasi di masyarakat dan bagaimana mereka menerapkan pembelajaran di kelas dalam kehidupan sehari-hari. Kompetensi guru dalam penilaian kinerja merupakan kemampuan yang harus dimiliki guru dalam proses pembelajaran. Menurut Abidin (2014) harus menguasai teknik pengembangan penilaian kinerja agar mampu menilai siswa (peserta didik) secara tepat, valid, dan reliable. Sehingga guru harus memiliki kompetensi penilaian kinerja.

Kompetensi yang harus dimiliki guru tentang penilaan kinerja masih terdapat permasalahan walaupun penilaian Kurikulum 2013 telah diterapkan sejak 2013. Sehingga, guru perlu memiliki bekal untuk beradaptasi dengan penilaian Kurikulum 2013 khusunya penilaian kinerja. Guru telah dibekali pengetahuan tentang penilaian kinerja dengan mengikuti pelatihan tentang pelaksanaan Kurikulum 2013 termasuk tentang penilaian kinerja. Selain itu pemerintah juga menyediakan beberapa buku panduan teknis yang diantaranya ada buku panduan teknis penilaian di Sekolah Dasar, petunjuk pengisian laporan hasil belajar peserta didik Sekolah Dasar serta pembelajaran remedial dan pengayaan di Sekolah Dasar.

Berdasarkan hasil wawancara awal yang dilakukan di SDN Blimbing 3 Kota Malang. Guru menyampaikan bahwa masalah yang ada dalam pelaksanaan penilaian kinerja yaitu pada waktu. Berkenaan dengan penilaian kinerja pada pembelajaran, pengamatan awal yang dilakukan di Kelas V SDN Blimbing 3 Kota Malang. Pada penerapan penilaian kinerja, guru tidak melakukan penilaian kinerja selama proses pembelajaran berlangsung. Sedangkan berdasarkan dokumen Rancangan Pelaksanaan Pembelajaran (RPP)
Tema Benda-benda di Lingkungan Sekitarku Subtema Perubahan Wujud Benda Pembelajaran 6, ditemukan permasalahan tentang perencanaan penilaian kinerja, yakni instrumen penilaian yang direncanakan guru tidak ada pedoman penskoran.

Berdasarkan uraian latar belakang yang telah dikemukakan di atas, rumusan masalah dalam penelitian ini, yaitu: (1) bagaimanakah guru merencanakan penilaian kinerja pada pembelajaran; (2) bagaimanakah guru menerapkan penilaian kinerja pada pembelajaran; dan (3) bagaimanakah guru melaporkan hasil penilaian kinerja pada pembelajaran di kelas V SDN Blimbing 3 Kota Malang?

\section{METODE}

Kasus yang diangkat dalam penelitian ini mengenai penerapan penilaian kinerja pada pembelajaran di kelas V SDN Blimbing 3 Kota Malang, khususnya pada perencanaan, penerapan, dan pelaporan hasil penilaian kinerja. Penelitian kualitatif ini mementingkan makna, dalam arti peneliti mengeksplorasi data sampai mendalam sehingga dapat menemukan makna dibalik data yang tampak atau terungkap. Jenis penelitian yang digunakan yaitu deskriptif kualitatif yang pada laporan penelitian berisi kutipan-kutipan data yang lengkap. Peneliti dalam penelitian ini berperan sebagai instrumen kunci (utama) selama pengumpulan data. Oleh karena itu, kehadiran di lapangan penelitian mutlak diperlukan. Peneliti hadir di SDN Blimbing 3 Kota Malang pada pembelajaran 2, pembelajaran 3 , dan pembelajaran 4 yang terdapat penilaian kinerja pada ketiga pembelajaran tersebut. Peneliti juga hadir di SDN Blimbing 3 Kota Malang pada hari lain untuk mencari data dengan teknik wawancara dan dokumen.

Penelitian ini dilaksanakan di SDN Blimbing 3 Kota Malang yang beralamatkan di Jalan Candi Kidal 3 Blimbing Malang Jawa Timur. Penelitian ini dilaksanakan karena belum pernah diadakan penelitian tentang penilaian kinerja di SD ini, sehingga ingin mengetahui penerapan penilaian kinerja pada pembelajaran di SDN Blimbing 3 Kota Malang khususnya kelas V. SDN ini merupakan SDN inti di gugus I Blimbing sehingga akan akan menggambarkan SDN imbas dari SDN inti ini. Penelitian ini membutuhkan sumber data untuk 
menunjang pemerolehan data yang diinginkan. Data dan sumber data pada penelitian ini yaitu guru kelas V sebagai informan, pelaksanaan penilaian kinerja, dan rapor peserta didik. Data tersebut diperoleh dari hasil wawancara, observasi dan dokumentasi. Data diperoleh dari informan jika data yang digali melalui wawancara dan observasi. Selain itu dalam penelitian ini juga digunakan teknik dokumentasi, sehingga sumber datanya berupa dokumen atau catatan-catatan yang telah ada.

Penelitian ini menggunakan jenis observasi partisipasi pasif. Kegiatan peneliti dalam observasi partisipasi pasif hanya bersifat sebagai pengamat yang hanya mencatat hal penting yang berkaitan dengan rumusan masalah. Observasi dilakukan pada penerapan penilaian kinerja pada pembelajaran kelas V SDN Blimbing 3 Kota Malang. Observasi dilaksanakan selama 3 hari pada pembelajaran 2, 3, dan 4. Pelaksanaan observasi menggunakan pedoman observasi dan membuat catatan lapangan yang berupa catatan tentang penerapan penilaian kinerja yang dilakukan oleh guru pada pembelajaran di kelas V SDN Blimbing 3 Kota Malang.

Peneliti akan mengumpulkan informasi melalui wawancara dengan subjek penelitian yaitu guru kelas $\mathrm{V}$ yang terlibat dalam tentang perencanaan penilaian kinerja, penerapan penilaian kinerja dan pelaporan hasil penilaian kinerja pada pembelajaran di kelas V SDN Blimbing 3 Kota Malang. Data wawancara diharapkan dapat lebih menjelaskan tentang tentang perencanaan penilaian kinerja, penerapan penilaian kinerja dan pelaporan hasil penilaian kinerja pada pembelajaran di kelas V SDN Blimbing 3 Kota Malang. Studi dokumentasi yang digunakan dalam penelitian ini digunakan untuk melihat perencanaan penilaian kinerja yang teriintegrasi pada perencanaan pelaksanaan pembelajaran (RPP) yang dibuat oleh guru, peneliti juga akan mengambil rapor di kelas V SDN Blimbing 3 Kota Malang.

Analisis data termasuk langkah yang sangat penting dilakukan agar data yang diperoleh atau terkumpul mempunyai arti dan dapat di tarik kesimpulan sebagai jawaban dari permasalahan yang diteliti. Analisis data dalam penelitian ini mengikuti analisis data yang dikembangkan oleh Miles dan Huberman, yaitu: (1) reduksi data;
(2) penyajian data; dan (3) verifikasi (Sugiyono, 2012). Pengecekan keabsahan temuan dilakukan setelah melakukan analisis data yang diperoleh dari data dan sumber data. Pengecekan dilakukan sampai ditemukan data yang benar-benar valid dan bisa dipertanggungjawabkan. Pengecekan keabsahan temuan pada penelitian ini dilakukan dengan ketekunan pengamatan, triangulasi, dan penggunaan bahan referensi.

\section{HASIL}

\section{Perencanaan Penilaian Kinerja pada Pembelajaran}

Mengenai perencanaan penilaian kinerja pada pembelajaran di keseluruhan Tema yang ada di Semester 2 di kelas V SDN Blimbing 3 Kota Malang diiketahui bahwa dalam perencanaan penilaian kinerja, guru kelas V SDN Blimbing 3 Kota Malang tidak menyiapkan perencanaan penilaian kinerja di Semester Genap yang terdiri dari Tema 5 sampai Tema 9 karena belum dijadikan satu RPP yang disusun oleh guru satu gugus I. Sehingga guru kelas $\mathrm{V}$ dalam perencanaan penilaian kinerja tidak ada penyusunan perencanaan penilaian kinerja, hal ini terbukti dari tidak adanya perencanaan penilaian kinerja yang teriintegrasi di dalam RPP di Semester Genap yang terdiri dari Tema 5 sampai Tema 9.

\section{Penerapan Penilaian Kinerja pada Pembelajaran}

Penerapan penilaian kinerja pada Semester Genap yang terdiri dari Tema 5 sampai Tema 9 tidak semua dilakukan oleh guru karena guru lebih memfokuskan penilaian kinerja nya sesuai dengan fokus materi, fokus penilaian kinerja, dan memperhatikan waktu yang dibutuhkan dalam melaksanakan penilaian.Penilaian Kinerja.

Penerapan penilaian kinerja pada Semester Genap yang terdiri dari Tema 5 sampai Tema 9 nampak belum sesuai dengan langkah-langkah penilaian kinerja yang seharusnya diterapkan oleh guru, karena guru tidak menyampaikan rubrik penilaian kinerja, waktu tidak terorganisir dengan baik, guru tidak melaksanakan penilaian kinerja karena guru tidak mengawasi pesera didik saat melaksanakan kinerja dan dalam menilai kinerja peserta didik guru tidak mengacu pada rubrik 
penilaian kinerja namun hanya mengingat-ingat rubrik penilaian kinerja saja sehingga kurang maksimal dalam menilai kinerja peserta didik.

\section{Pelaporan Penilaian Kinerja pada Pembelajaran}

Pengolahan nilai penilaian kinerja dengan skor optimum dan rata-rata dari skor yang diperoleh. Pelaporan penilaian kinerja di pembelajaran yang terdiri dari Tema 5 sampai Tema 9 di kelas V SDN Blimbing 3 Kota Malang berbentuk angka dengan deskripsi yang bermakna. Guru memiliki kesulitan pada waktu pengolahan nilai pesera didik karena guru harus mengolah nilai semua nilai peserta didik per Kompetensi Dasar.

\section{PEMBAHASAN}

\section{Perencanaan Penilaian Kinerja pada Pembelajaran}

Guru tidak menyusun perencanaan penilaian kinerja yang terintegrasi di dalam Rencana Pelaksanaan Pembelajaran karena guru tidak memiliki RPP di Semester Genap yang terdiri dari Tema 5 sampai Tema 9. Namun guru melaksanakan penilaian kinerja sama seperti yang tertuang dalam buku guru. Secara rasional, guru berkewajiban menyusun perencanaan penilaian yang teriintegrasi dalam RPP, hal ini sesuai dengan pernyataan (Kemendikbud, 2013).

Perencanaan penilaian yang disusun oleh guru dilakukan saat guru menyusun RPP. Penilaian memerlukan perencanaan penilaian yang sistematis, hal ini sesuai dengan pernyataan Peraturan Menteri Pendidikan dan Kebudayaan Nomor 53 Tahun 2015 tentang Penilaian Hasil Belajar oleh Pendidikan pada Pendidikan pada Pendidikan Dasar dan Pendidikan Menengah (Kemendikbud, 2015). Lebih lanjut tentang prinsip penilaian yang seharusnya sistematis. Penilaian memerlukan perencanaan yang bertahap sesuai dengan langkah yang telah ditetapkan, hal ini sesuai dengan pernyataan Kemendikbud (2015).

\section{Penerapan Penilaian Kinerja pada Pembelajaran di kelas V SDN Blimbing 3 Kota Malang}

Guru memiliki kesulitan dalam waktu penerapan penilaian kinerja. Seharusnya dalam satu pembelajaran terdapat lebih dari satu penilaian kinerja tetapi guru lebih memfokuskan pada penilaian kinerja. Terbukti pada Tema 8 Subtema 2 Pembelajaran 2 guru memfokuskan pada penilaian kinerja membuat majalah dinding tema ekosistem, pada Pembelajaran 3 memfokuskan pada penilaian kinerja bermain peran, dan pada Pembelajaran 4 memfokuskan pada penilaian kinerja menulis syair dan membaca syair.

Penerapan penilaian kinerja pada Tema 5 sampai Tema 9 nampak belum sesuai dengan langkah-langkah penilaian kinerja yang seharunya diterapkan oleh guru berdasarkan hasil temuan peneliti terhadap penerapan penilaian kinerja pada Tema 8 Subtema 2 Pembelajaran 2 yang berfokus membuat majalah dinding tema ekosistem nampak belum sesuai dengan langkah-langkah penilaian kinerja, karena guru tidak menyampaikan rubrik penilaian kinerja membuat majalah dinding tema ekosistem, waktu tidak terorganisir dengan baik, dan dalam menilai kinerja peserta didik guru tidak membawa rubrik penilaian kinerja membuat majalah dinding tema ekosistem namun hanya mengingat-ingat rubrik penilaian kinerja saja sehingga kurang maksimal dalam menilai kinerja peserta didik.

Hal ini tidak sejalan dengan pernyataan Kunandar (2014) bahwa langkah yang harus dilakukan dalam menerapkan penilaian unjuk kerja atau praktik adalah: (1) guru menyampaikan rubrik sebelum pelaksanaan penilaian kepada peserta didik; (2) guru memberikan pemahaman yang sama kepada peserta didik tentang kriteria penilaian; (3) guru menyampaikan tugas kepada peserta didik; (4) guru memeriksa kesediaan alat dan bahan yang digunakan untuk tes praktik; (5) guru melaksanakan penilaian selama rentang waktu yang direncanakan; (6) guru membandingkan kinerja peserta didik dengan rubrik penilaian; (7) melakukan penilaian dilakukan secara individual; (8) mencatat hasil penilaian; dan (9) mendokumentasikan hasil penilaian.

\section{Pelaporan Penilaian Kinerja pada Pembelajaran}

Pelaporan penilaian kinerja yang dilakukan oleh guru kelas $\mathrm{V}$ berbentuk angka dengan deskripsi yang bermakna. Hal ini sesuai dengan Kemendikbud (2015) yang menyatakan di tingkat 
Sekolah Dasar pelaporan dilakukan oleh guru kelas. Proses pelaporan sendiri bisa dilakukan secara tertulis yang tertuang dalam rapor yang diberikan setiap akhir semester. Pelaporan keterampilan dapat ditulis dengan angka, predikat, dan deskripsi untuk masing-masing muatan pelajaran. Deskripsi keterampilan ditulis dengan kalimat positif sesuai dengan capaian $\mathrm{KD}$ tertinggi dan terendah dari masing-masing muatan pelajaran yang diperoleh peserta didik.

\section{SIMPULAN DAN SARAN}

\section{Simpulan}

Kesimpulan dari penelitian ini yaitu perencanaan penilaian kinerja yang dilakukan guru di Semester Genap yang terdiri dari Tema 5 sampai Tema 9 tidak ada penyusunan perencanaan penilaian kinerja karena guru tidak menyusun RPP. Penerapan penilaian kinerja di Semester Genap yang terdiri dari Tema 5 sampai Tema 9 tidak terlaksana semuanya karena guru kesulitan pada waktu perlaksanaannya dan guru terfokus pada satu materi dengan satu penilaian kinerja. Penerapan penilaian kinerja yang dilakukan oleh guru di Semester Genap yang terdiri dari Tema 5 sampai Tema 9 belum sepenuhnya sesuai dengan langkahlangkah penilaian kinerja. Pelaporan penilaian kinerja yang dilakukan oleh guru yaitu sudah baik, hal ini terbukti dari pelaporan penilaian kinerja di rapor berbentuk angka, predikat, dan deskripsi yang bermakna. Namun guru memiliki kesulitan waktu dalam pengolahan nilai peserta didik.

\section{Saran}

Berdasarkan kesimpulan hasil penelitian di atas, maka saran yang diajukan sebagai berikut. Disarankan bagi Kepala sekolah agar dapat memonitor guru dalam perencanaan penilaian kinerja yang teriintegrasi dalam RPP, memberikan pelatihan dalam mengembangkan perencanaan penilaian kinerja dan memberikan penguatan dalam memperbaiki proses penilaian kinerja yang belum terlaksana sebagaimana yang seharusnya dalam pelaksanaan penilaian kurikulum 2013. Bagi guru hendaknya menyiapkan perencanaan penilaian yang didalamnya terintegrasi rubrik penilaian kinerja dan tidak berpedoman langsung dengan buku guru. Bagi peneliti lain yang berkeinginan untuk mengembangkan penelitiannya tentang penilaian kinerja, dapat melakukan penelitian tentang perencanaan penilaian kinerja yang terintegrasi dalam RPP dengan menambahkan penerapan penilaian kinerja selain di Pembelajaran 2, Pembelajaran 3, dan Pembelajaran 4.

\section{DAFTAR RUJUKAN}

Abidin, Y. 2014. Desain Sistem Pembelajaran dalam Konteks Kurikulum 2013. Bandung: PT Refika Aditama.

Kemendikbud. 2013. Implementasi Kurikulum 2013 Penyusunan Rencana Pelaksanaan Pembelajaran (RPP) SD/SMP/SMA/SMK. Jakarta: Kementerian Pendidikan dan Kebudayaan.

Kemendikbud. 2015. Panduan Penilaian untuk Sekolah Dasar. Jakarta: Direktorat Pembinaan Sekolah Dasar, Direktorat Jenderal Pendidikan Dasar, Kementerian Pendidikan dan Kebudayaan.

Kunandar. 2014. Penilaian Autentik (Penilaian Hasil Belajar Peserta Didik Berdasarkan Kurikulum 2013) Suatu Sistem Praktis dengan Contoh. Jakarta: PT Rajagrafindo Persada.

Peraturan Menteri Pendidikan dan Kebudayaan Nomor 53 Tahun 2015 tentang Penilaian Hasil Belajar oleh Pendidikan pada Pendidikan pada Pendidikan Dasar dan Pendidikan Menengah. Bandung: Citra Umbara.

Sugiyono. 2012. Metode Penelitian Pendidikan Kualitatif dan $R \& D$. Bandung: Alfabeta. 